\title{
Dear Mr. Bolotin: I Wish It Were Only That Bad
}

\section{David Acevedo}

When I began my undergraduate studies at Columbia, I asked a new friend what his major was. He somewhat facetiously replied, “I'm majoring in what it means to be a human.” At the time, I had no idea what he was talking about, but years later it "clicked”-regardless of this fellow's official program of study, he was primarily concerned with something much greater: the "humanities" in their fullest sense. Meanwhile, the humanities as a sector of academia are rapidly dwindling, due to the growing scarcity of humanities-based core curricula, fewer students majoring in or interested in these fields, and the intellectual degradation of said fields where they are still taught. ${ }^{1}$ This has had far-reaching consequences for higher education and the country as a whole, the effects of which we are just beginning to see.

David Bolotin certainly recognizes this decline. And yet his analysis of contemporary education in "Liberal Education and Politics" ${ }^{2}$ misses the totality of the illiberal rot that has all but destroyed the humanist educational ideal and that now pervades all levels of American education; indeed, the problem is far more severe than he describes.

Take, for example, Bolotin's description of "the ruling opinions of our own political society”: “These are, I think, a belief in equality and a belief in freedom. We are taught that we are all equal, and we are also taught that we have the right to a very great degree of freedom ... " He then claims that such "equality" has come to mean equality of outcomes, not equality of opportunity. This is true to an extent, but even the concept of equality is now out of style, to be replaced by its nefarious cousin, "equity." ${ }^{3}$ That is, it's no longer enough to insist on equal

1 Mark Bauerlein, "The Few, the Proud, the Profs," Academic Questions 34, no.1 (Spring, 2021).

2 David Bolotin, "Liberal Education and Politics," Minding the Campus, December 23, 2020.

3 Specifically the Left's contemporary definition of equity. For an excellent analysis of the history and development of the term, see James Druley, Ray M. Sanchez, and David Richardson, "The Evolution and Implementation of Equity (Part I)," Minding the Campus, February 18, 2021; "The Evolution and Implementation of Equity (Part II)," Minding the Campus, February 25, 2021.

David Acevedo is communications \& research associate for the National Association of Scholars and a graduate of Columbia University. 
treatment, or even equal outcomes. We must rather handicap the "privileged" in favor of the "oppressed" in student admissions, faculty hiring, and classroom instruction, therefore creating artificial, unequal outcomes favoring allegedly oppressed groups. Equality, even equality of outcomes, is outdated and has been supplanted by a reparations-centered form of equity.

Then there's “freedom.” Freedom is virtually absent from American education, and where it is present, it is mishandled. For example, as David Randall explains in his critique of the College Board's Advanced Placement history courses and examinations, “The very words liberty and freedom appear extraordinarily rarely" in both AP European History and AP U.S. History [emphasis in original]. ${ }^{4}$ A recently published NAS critique of five widely used American history textbooks tells the same story. ${ }^{5}$ These are two examples among manysadly, Bolotin's assertion that we're all taught "a belief in freedom” no longer holds true.

Bolotin goes on to say "freedom requires a questioning of all inherited assumptions, including the most fundamental assumptions of one's political society-not necessarily a rejection of them, but at least an openness to the possibility that they are wholly or partly false." When I was at Columbia-ostensibly one of the last great books programs remaining-we were taught something very different: necessarily reject all inherited assumptions and adopt a new set of assumptions and values that must not be questioned under any circumstances.

This mode of "education" is illustrated perfectly by the Butler Banner Project of 2019. ${ }^{6}$ Columbia's Butler Library is a landmark well known for its ionic columns and chandelier-illumined reading rooms, as well as the names of select great men carved on its façade whose work has shaped Western Civilization: Homer, Herodotus, Sophocles, and Vergil, to name a few. This list was first amended (defaced) in 1989, when an undergraduate student hung a new banner above the old, displaying the names of women she saw as equally, or even more, important: Sappho, Emily Dickinson, Virginia Woolf, etc. This ersatz banner was soon taken down, and while different students attempted the same stunt again in 1994, it ended in a similar fashion.

4 David Randall, Disfigured History: How the College Board Demolishes the Past, National Association of Scholars, November 15, 2020, https://www.nas.org/reports/disfigured-history/full-report.

5 David Randall, et al., Skewed History: Textbook Coverage of Early America and the New Deal, April 27, 2021.

6 https://www.butlerbanner.com. 
Fast-forward twenty-five years, when students inspired by their ideological foremothers created a new, sufficiently woke banner to hang on Butler Library. Apparently, the earlier banners featured too many white women, so some of my peers compiled an intersectional coalition of female thinkers to emblazon on their banner, including Maya Angelou, Zora Neale Hurston, Toni Morrison, and A. Revathi (the last of whom is actually a man). In addition to the new banner's much higher melanin level, this time was different for another reason: Columbia's administration sanctioned the Butler Banner Project and allowed the new banner to remain on display for an entire semester. What were once attempts to change the Western canon by guerilla feminists are now institutionally approved, indeed, mandated changes that must be obeyed.

Today's higher ed progressives have no problem with the idea of a canon. They simply want to dispose of the old canon and establish their own. Indeed, they seek to "dismantle” Western Civilization, the bedrock of which is its canon, precisely because they see the West as oppressive to "marginalized" groups. This "liberation" has virtually nothing to do with individual equality or freedom (which both get in the way) and everything to do with a lust for power, and thereby punishment, shame, and redress of “victimization." Hence, a vision of justice as retribution, grounded in group identity-that is, no justice at all. The consequences of this shift in canon have been, and will be, catastrophic. Out with equality and freedom. In with postmodern secularism and, thereby, totalitarian self-destruction.

Is there anything to be done? For starters, my own view is that each of us needs to take up, with courage, the "major" of my facetious friend: to return to the rigorous, disinterested study of what it means to be a human, within or without the academy. To be clear, I am not saying we must cloister ourselves, quivering among our books. Rather, we must remember that the humanities are an essential part of the response to higher ed's neo-racialist tribalism: to be a full human being, not some angry or ashamed member of a favored or disfavored group. So go ahead, crack open that old copy of The Iliad and truly read it. This may be just what America needs to survive. 